\title{
Proton Diet for the Sodium Pump
}

\author{
Hans-Jürgen Apell,* Gabriela Benz, and Daniel Sauerbrunn \\ Department of Biology, University of Konstanz, 78464 Konstanz, Germany
}

\begin{abstract}
In the absence of $\mathrm{Na}^{+}$and $\mathrm{K}^{+}$ions the $\mathrm{Na}, \mathrm{K}$-ATPase shows a $\mathrm{pH}$-dependent ATP hydrolysis that can be inhibited by ouabain. At pH 7.2 this activity is $5 \%$ of the maximal under physiological conditions. It could be inferred that this activity is associated with $\mathrm{H}^{+}$transport in both directions across the membrane and facilitates an $\mathrm{H}$-only mode of the sodium pump under such unphysiological conditions. By the analysis of experiments with reconstituted proteoliposomes an overall electroneutral transport mode has been proven. The stoichiometry was determined to be $2 \mathrm{H}^{+} / 2 \mathrm{H}^{+} / 1 \mathrm{ATP}$ and is comparable to what is known from the closely related H,K-ATPase. By time-resolved ATP-concentration jump experiments it was found that at no time was the third, $\mathrm{Na}^{+}$-specific binding site of the pump occupied by protons. A modified Post-Albers pump cycle is proposed, with $\mathrm{H}^{+}$ions as congeners for $\mathrm{Na}^{+}$and $\mathrm{K}^{+}$, by which all experiments performed can be explained.
\end{abstract}

The Na,K-ATPase is a vital active ion transporter in almost all animal cells, and it maintains the electrochemical potential gradients for $\mathrm{Na}^{+}$and $\mathrm{K}^{+}$ions across the cytoplasmic membrane. The principal pump mechanism was identified more than 4 decades ago $(1,2)$ and is represented by the so-called Post-Albers cycle (Figure 1). In the meanwhile this concept is used as a basis to describe transport and enzymatic function not only of the Na,K-ATPase but of many other P-type ATPases, too (3). The main feature of this pump cycle is that there are two principal conformations in which the ion-binding sites are accessible from either cytoplasm $\left(\mathrm{E}_{1}\right)$ or the extracellular (or luminal) side $\left(\mathrm{P}-\mathrm{E}_{2}\right)$. Between both conformations that allow ions to access the binding sites, so-called occluded states are intercalated which prevent simultaneous passage between ion-binding sites and both aqueous phases, a condition which would produce an electric short circuit across the cell membrane. A second characteristic feature of the pump cycle is the pingpong mode of the $\mathrm{Na}, \mathrm{K}$-ATPase which implicates a consecutive transport of $\mathrm{Na}^{+}$and $\mathrm{K}^{+}$, each transported by one-half of the pump cycle. P-type ATPases share a (eponymous) phosphorylated intermediate in which the $\gamma$-phosphate of the ATP is transferred to a highly conserved aspartate located at the $\mathrm{P}$ domain of the protein.

Since the introduction of the Post-Albers cycle the pump process of the Na,K-ATPase was tested under various, partly extremely unphysiological conditions to gain a deeper and more detailed understanding of the molecular transport mechanism. In the framework of these studies different flux modes were detected. For review see ref 4 . Besides the physiological pump mode with a $3 \mathrm{Na}^{+} / 2 \mathrm{~K}^{+}$stoichiometry which is driven by ATP hydrolysis and maintains the cytoplasmic $\mathrm{Na}^{+}$concentration low and the $\mathrm{K}^{+}$concentration

†This work was financially supported by the AFF of the University of Konstanz, Grant 04/68.

*Dedicated to Robert L. Post on the occasion of his 90th birthday.

*To whom correspondence should be addressed. Phone: +497531 882253. Fax: +49 7531 883183. E-mail: h-j.apell@uni-konstanz.de.

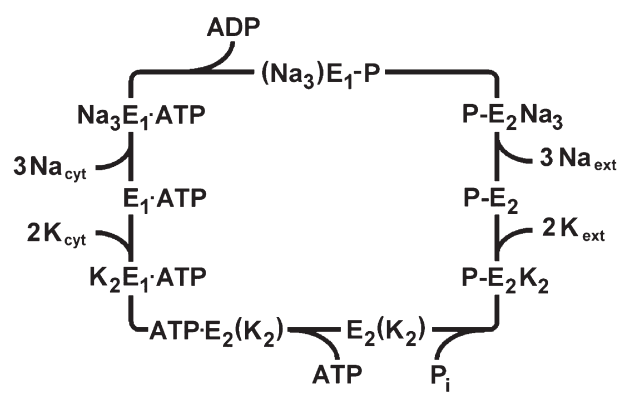

Figure 1: The Post-Albers scheme describes the pump cycle of the $\mathrm{Na}, \mathrm{K}-\mathrm{ATPase}$ under physiological conditions. In the $\mathrm{E}_{1}$ conformation the ion-binding sites are accessible to the cytoplasm and allow exchange of two potassium ions against three sodium ions. In the $\mathrm{E}_{2}$ conformation the reverse exchange is performed with the extracellular medium. In the "occluded" states, $\left(\mathrm{Na}_{3}\right) \mathrm{E}_{1}-\mathrm{P}, \mathrm{E}_{2}(\mathrm{~K})_{2}$, and $\mathrm{ATP} \cdot \mathrm{E}_{2}(\mathrm{~K})_{2}$, the ions bound are trapped inside the membrane domain, unable to exchange with either aqueous phase. The upper half-cycle is ATP driven and transports sodium ions. The lower halfcycle is controlled by enzyme dephosphorylation and works (under unphysiological conditions) also with congeners of $\mathrm{K}^{+}$ions, such as $\mathrm{Rb}^{+}, \mathrm{Cs}^{+}, \mathrm{H}^{+}$, or even $\mathrm{Na}^{+}$.

high, several noncanonical modes were found when appropriately different substrate compositions were chosen on both sides of the membrane: (i) a reverse mode in which ATP synthesis is driven by inversion of the ion gradients and the membrane potential, (ii) an $\mathrm{Na}^{+}-\mathrm{Na}^{+}$exchange mode without net ATP hydrolysis (ATP-ADP exchange) and without net $\mathrm{Na}^{+}$transport, (iii) a $\mathrm{K}^{+}-\mathrm{K}^{+}$exchange which requires only the presence inorganic phosphate without net $\mathrm{K}^{+}$transport, and (iv) a $\mathrm{Na}^{+}-\mathrm{X}^{+}$exchange, in which $\mathrm{X}^{+}$is a monovalent cation ion, a congener that is able to substitute $\mathrm{K}^{+}$, mostly less effective than $\mathrm{K}^{+}$but with the same stoichiometry of $3 \mathrm{Na}^{+} / 2 \mathrm{X}^{+} . \mathrm{X}^{+}$can even be $\mathrm{Na}^{+}$, which leads to an electrogenic, ATP-consuming $\mathrm{Na}^{+}-\mathrm{Na}^{+}$exchange. An originally named "uncoupled $\mathrm{Na}^{+}$efflux", the so-called Na-only mode, which was found to be ATP consuming, later turned out to be a $\mathrm{Na}^{+}-\mathrm{H}^{+}$exchange which can be subsumed in category iv. Replacement of $\mathrm{K}^{+}$by protons has been documented by 
several experimental studies using IOVs ${ }^{1}$ derived from human red cells (5), from reconstituted proteoliposomes (6), or in purified microsomal membrane preparations $(7,8)$.

While in the $\mathrm{K}^{+}$-transferring half-cycle various congeners are readily accepted by the Na,K-ATPase, it was found that the $\mathrm{Na}^{+}$-transferring and ATP-hydrolyzing half-cycle is highly specific to $\mathrm{Na}^{+}$ions. This may have mechanistic reasons since it was shown that binding of the third $\mathrm{Na}^{+}$induces a conformational effect on the cytoplasmic domain of the protein that acts as a trigger signal for enzyme phosphorylation (9). Nevertheless, earlier studies showed that $\mathrm{Li}^{+}$is able to replace $\mathrm{Na}^{+}$in the pump cycle with very low efficiency $(10,11)$. A stoichiometry of $1 \mathrm{Li}^{+} /$ $1 \mathrm{~K}^{+}$was found in human erythrocytes (11), indicating an electroneutral exchange. More detailed investigations were performed to test the replacement of $\mathrm{Na}^{+}$by protons $(5,12-15)$.

IOVs were used to demonstrate that in the absence of cytoplasmic $\mathrm{Na}^{+}$deceasing $\mathrm{pH}$ led to increased ATP hydrolysis, produced $\mathrm{a} \mathrm{Rb}^{+}$efflux, and could be inhibited by strophanthidin $(5,12,15)$. Enzyme phosphorylation by ATP could be detected in the absence of $\mathrm{Na}^{+}$, and the yield of the reaction was increased with decreased $\mathrm{pH}(15)$. In addition, it was found that the $\mathrm{Na}^{+}$/ATP coupling ratio was decreased with decreasing $\mathrm{pH}$ (5). Proteoliposomes with reconstituted $\mathrm{Na}, \mathrm{K}$-ATPase were used to study the $\mathrm{H}^{+}, \mathrm{K}^{+}$transport mode of the Na,K-ATPase in the absence of $\mathrm{Na}^{+}$, and it was found that $\mathrm{pH}$-dependent uptake of $\mathrm{H}^{+}$could be induced by ATP (13). Finally, purified microsomal membrane preparations from pig kidney were used to show that protons can activate ATPase activity in place of $\mathrm{Na}^{+}$in the presence of $\mathrm{K}^{+}$with an optimum at $\mathrm{pH} 5.7$ (14).

On the basis of these more phenomenological descriptions of the role of cytoplasmic protons for the pump function of the $\mathrm{Na}$, K-ATPase, we revisited this noncanonical transport mode with a different and more advanced experimental technique to gain insight into mechanistic details. The electrochromic styryl dye RH421 has already been applied in numerous studies to reveal details on ion-binding and release reactions, the number of ions present in the binding sites, and the time-dependent resolution of reaction sequences and their kinetic parameters $(16-21)$. The results presented in the following shall be used to propose a $\mathrm{H}^{+}$ pump mechanism that allows a mechanistic explanation of previously published and our new data.

\section{MATERIALS AND METHODS}

Materials. Phosphoenolpyruvate (PEP), pyruvate kinase, lactate dehydrogenase, NADH, and BSA, were ordered from Boehringer. The electrochromic styryl dye RH421, oxonol VI, and NPE-caged ATP were ordered from MoBiTec (Göttingen, Germany). All other reagents were purchased from Merck or Sigma-Aldrich at the highest quality available.

Na,K-ATPase-Containing Membrane Preparations. Purified membrane preparations with a high concentration of $\mathrm{Na}, \mathrm{K}$ ATPase ( 5.000 pumps per $\left.\mu \mathrm{m}^{2}\right)$ were prepared from the outer medulla of rabbit kidneys using procedure $\mathrm{C}$ of Jørgensen (22). The enzyme activity of the Na,K-ATPase (23) was determined in

\footnotetext{
${ }^{1}$ Abbreviations: IOVs, inside-out membrane vesicles; RH421, $N$-(4sulfobutyl)-4-(4-( $p$-(dipentylamino)phenyl)butadienyl)pyridinium inner salt; NADH, nicotinamide adenine dinucleotide; EGTA, 3, 12-bis(carboxymethyl)-6,9-dioxa-2,12-diazatetradecanedioic acid; DOPC, 1,2-dioleoyl$s n$-glycero-3-phosphocholine; oxonol VI, bis(3-propyl-5-oxoisooxazol4-yl)pentamethine oxonol; NPE-caged ATP, $P^{3}$-(1-(2-nitrophenyl)ethyl)adenosine $5^{\prime}$-triphosphate; TM, transmembrane domain.
}

buffer containing $25 \mathrm{mM}$ imidazole, $\mathrm{pH} 7.2,100 \mathrm{mM} \mathrm{NaCl}$, $10 \mathrm{mM} \mathrm{KCl}, 5 \mathrm{mM} \mathrm{MgCl} 2,1.5 \mathrm{mM}$ ATP, 2 mM PEP, 450 units/ $\mathrm{mL}$ pyruvate kinase and lactate dehydrogenase, and initially $80 \mu \mathrm{M}$ NADH. The specific ATPase activity of the membrane preparations used was in the range of $1800-2000 \mu \mathrm{mol}$ of $\mathrm{P}_{\mathrm{i}}$ (mg of protein) $)^{-1} \mathrm{~h}^{-1}$ at $37^{\circ} \mathrm{C}$. The enzyme activity could be completely blocked in the presence of $100 \mu \mathrm{M}$ ouabain. The ouabain-insensitive activity of the preparations was $<1 \%$.

Enzyme Activity Assay. ATPase activity in $\mathrm{Na}^{+}$and/or $\mathrm{K}^{+}$ free buffer was measured by determination of the released inorganic phosphate, $\mathrm{P}_{\mathrm{i}}$, using a malachite green assay (24): The membrane fractions were incubated at $37^{\circ} \mathrm{C}$ for $1 \mathrm{~h}$ in buffer containing $25 \mathrm{mM}$ histidine, $0.5 \mathrm{mM}$ EDTA, and $1 \mathrm{mM} \mathrm{MgCl}$, $\mathrm{pH} 7.2$, with and without $1 \mathrm{mM}$ ouabain, and other indicated substrate ions. Pump activity was started by addition of $0.5 \mathrm{mM}$ MgATP. The Na,K-ATPase-specific enzyme activity was determined as the difference between the measurements without and with ouabain.

Detection of Partial Reactions by the Electrochromic Styryl Dye RH421. Fluorescence experiments with low time resolution were performed with a self-constructed setup using a HeNe laser with a wavelength of $594 \mathrm{~nm}$ (Laser 2000, Wessling, Germany) to excite the fluorescence of the electrochromic styryl dye RH421 as described recently (25). The light emitted perpendicularly to the incident laser light was collected, filtered by a narrow-band interference filter $\left(\lambda_{\max }=663 \mathrm{~nm}\right.$, half-width $18 \mathrm{~nm}$ ), and detected by a head-on photomultiplier (R2066, Hamamatsu Photonics, Hamamatsu City, Japan). The photo current was amplified and digitized with a sampling frequency between 1 and $10 \mathrm{~Hz}$. The temperature in the cuvette $(2 \mathrm{~mL})$ was maintained at $20{ }^{\circ} \mathrm{C}$ by thermostatic control. All RH421 experiments were performed with open membrane fragments so that the indicated buffer composition accessed both interfaces of the $\mathrm{Na}, \mathrm{K}$-ATPase. To allow a comparison between different fluorescence experiments, relative fluorescence changes, $\Delta F / F_{0}=$ $\left(F-F_{0}\right) / F_{0}$, were calculated with respect to the initial reference level, $F_{0}$.

Time-Resolved Fluorescence Measurements. For data recording of fluorescence signals with high time resolution a setup was modified, whose design was published earlier (26). A cylindric quartz cuvette (internal diameter, $7.8 \mathrm{~mm}$ ) containing $300 \mu \mathrm{L}$ of electrolyte solution was placed in the upper focus of an ellipsoidal mirror (Melles Griot, Zevenaar, Netherlands) whose opening was directed downward. The electrolyte for ATP-jump experiments contained $100 \mu \mathrm{M}$ caged ATP which was added only shortly before the experiment. Handling of the cuvette was performed in darkened environment. The fluorescent dye in the solution was excited by a $594 \mathrm{~nm}$ HeNe laser from the top of the setup. A quartz lens was adjusted to widen the laser beam and to illuminate the whole solution almost homogeneously. The emitted light was collected by the ellipsoidal mirror and reflected into the second focus of the mirror. An interference light filter $(663 \pm 18 \mathrm{~nm})$ selected the emitted light of the styryl dye before passing the entrance window of a photomultiplier (PM, R928, Hamamatsu Photonics, Japan). An additional UV cutoff filter reduced the effect of the UV-laser flash which is applied to photocleave the caged compound. The output current was amplified and digitized by a 12-bit data acquisition board of a PC with sampling frequencies between 1 and $500 \mathrm{kHz}$. The bottom of the cuvette was in contact with a thermostated copper socket (that also stopped the incident light). The observed phosphorylation of the Na,K-ATPase by ATP was triggered by a UV flash from an 
EMG 100 excimer laser (Lambda Physics, Göttingen, Germany; duration $14 \mathrm{~ns}$, wavelength $351 \mathrm{~nm}$, maximum power $6 \mathrm{MW}$ ) that released $10 \mu \mathrm{M}$ ATP (corresponding to a yield of $10 \%$ ) from its caged precursor, NPE-caged ATP.

Detection of Membrane Potential in Proteoliposomes. $\mathrm{Na}, \mathrm{K}-\mathrm{ATPase}$ containing DOPC vesicles was obtained by dialysis from cholate-solubilized protein and lipids as described before (27). The dialysis buffer contained $25 \mathrm{mM}$ histidine, $0.5 \mathrm{mM}$ EDTA, $5 \mathrm{mM} \mathrm{MgCl}$, and $140 \mathrm{mM} \mathrm{NaCl}, \mathrm{pH} 7.3$. Dialysis against cholate-free buffer was performed for 3 days. At the end of the dialysis an enzyme activity of $184.6 \mu \mathrm{mol}$ of $\mathrm{P}_{\mathrm{i}}(\mathrm{mg}$ of protein) ${ }^{-1} h^{-1}$ was detected. To remove the $\mathrm{Na}^{+}$ions from the electrolyte, the vesicles were redialyzed for up to 3 days in buffer in which $\mathrm{NaCl}$ was exchanged against $130 \mathrm{mM}$ choline chloride. Dialysis of the vesicles in sodium-free buffer from the beginning led to a significant inactivation of the Na,K-ATPase. The electrogenic pump activity of the Na,K-ATPase was detected in buffer without or with $140 \mathrm{mM} \mathrm{NaCl}$; the $\mathrm{pH}$ was adjusted between 7.3 and 6.0 by addition of $\mathrm{HCl}$. Oxonol VI was added in a concentration of $95 \mathrm{nM}$ to the electrolyte to monitor the pumpinduced changes of the membrane potential as described before (28). The pump activity was initiated by addition of $100 \mu \mathrm{M}$ MgATP. Although the Na,K-ATPase is reconstituted in the vesicle membrane in both orientations, inside out and right side out, only inside-out oriented pumps are able to contribute to the pump activity since the ATP added to the buffer is unable to permeate through the lipid bilayer into the vesicle lumen to activate the right-side-out oriented pumps.

\section{RESULTS}

Ion Dependence of the Enzyme Activity. The ATP-hydrolyzing activity of the Na,K-ATPase in buffers of different cation composition was determined using the malachite green assay. A reference activity of $1960 \mu \mathrm{mol}$ of $\mathrm{P}_{\mathrm{i}}(\mathrm{mg} \text { of protein })^{-1} \mathrm{~h}^{-1}$ at $37^{\circ} \mathrm{C}$ was obtained with the purified microsomal Na,K-ATPase preparation in the (near physiological) $\mathrm{Na}, \mathrm{K}$ mode in buffer containing $130 \mathrm{mM} \mathrm{NaCl}$ and $20 \mathrm{mM} \mathrm{KCl}$. In buffer containing $130 \mathrm{mM} \mathrm{NaCl}$ but no $\mathrm{KCl}$ the enzyme activity was determined to be $40 \pm 1.3 \%$ of that in the $\mathrm{Na}, \mathrm{K}$ mode (Figure $2 \mathrm{~A}$ ). In the $\mathrm{K}$-only mode $(20 \mathrm{mM} \mathrm{KCl}$ and $0 \mathrm{NaCl})$ only a negligible residual activity of $1.8 \pm 1.8 \%$ was detected. In the absence of both $\mathrm{Na}^{+}$ and $\mathrm{K}^{+}$, when protons were the only cations present, ATPase activity could be found to be $5.0 \pm 0.6 \%$ at $\mathrm{pH} 7.2$ and $23.3 \pm$ $1.2 \%$ at $\mathrm{pH} 6.0$. This activity could be inhibited completely by $1 \mathrm{mM}$ ouabain. To analyze the $\mathrm{pH}$ dependence of the ATPase activity in the absence of $\mathrm{Na}^{+}$and $\mathrm{K}^{+}$, experiments were performed at various $\mathrm{pHs}$ between 5.8 and 7.2 (Figure 2B). With a molar mass of $135 \mathrm{kDa}$ the enzyme activity of the Na,K-ATPase was transformed into a hydrolysis rate and plotted against the buffer $\mathrm{pH}$. The $\mathrm{pH}$ dependence of the ATP activity (full circles) could be fitted by the Hill function:

$$
v(\mathrm{pH})=\left(v_{\max }-v_{\min }\right) \frac{10^{-n_{\mathrm{H}} \mathrm{pH}}}{10^{-n_{\mathrm{H}} K}+10^{-n_{\mathrm{H}} \mathrm{pH}}}+v_{\min }
$$

where $v_{\min }$ and $v_{\max }$ are the hydrolysis rates at high and low $\mathrm{pH}$, respectively, $n_{\mathrm{H}}$ is the Hill coefficient, and $\mathrm{pK}$ is the halfsaturating $\mathrm{pH}$ of the process. According to the fit, at low $\mathrm{pH}$, i.e., saturating $\mathrm{H}^{+}$concentration, the hydrolysis rate, $v_{\max }$, was $17 \pm$ $0.7 \mathrm{~s}^{-1}$; at high $\mathrm{pH}$ the rate stabilized at $7 \pm 0.1 \mathrm{~s}^{-1}$. Increasing the proton concentration accelerated the ATP hydrolysis up to 2.4-fold. The $\mathrm{p} K$ which reflects an apparent dissociation constant
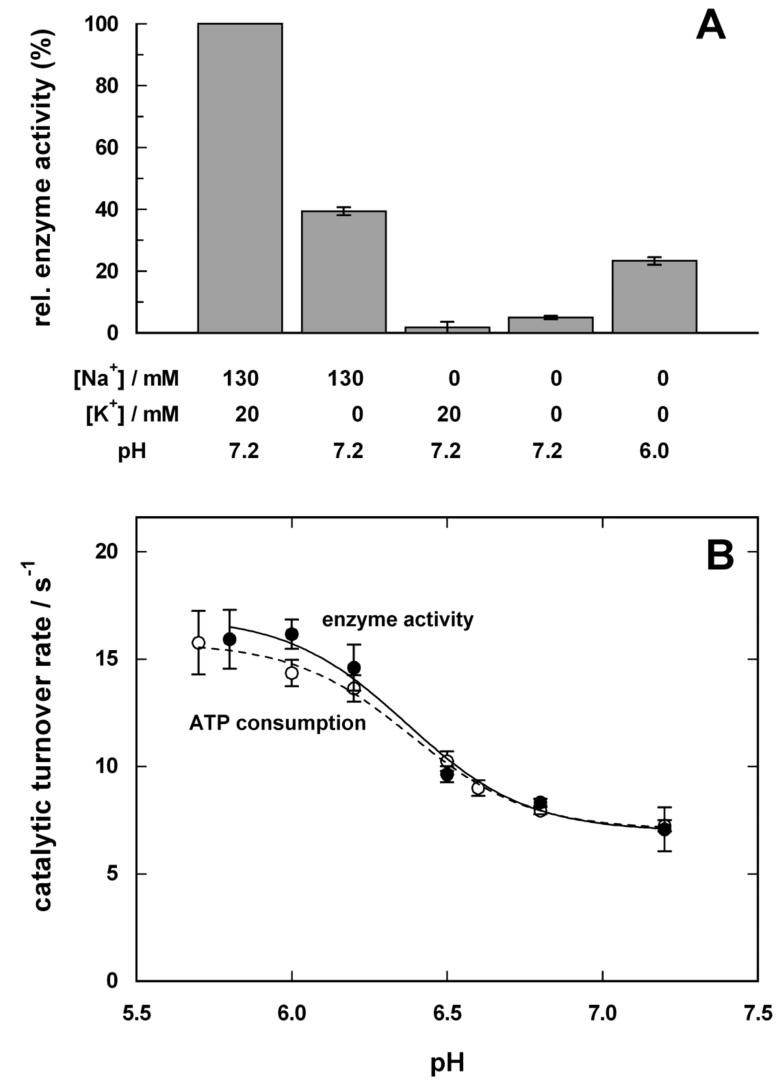

FIgURE 2: Enzyme activity of purified Na,K-ATPase isolated from rabbit kidney determined by the amount of inorganic phosphate released. (A) ATP hydrolysis rate obtained in the presence of various monovalent cation concentrations. The cation concentrations are specified below the respective bars and represent from left to right the physiological $\mathrm{Na}, \mathrm{K}$ mode, the Na-transporting mode, the K-only mode, and the proton-only mode at $\mathrm{pH} 7.2$ and 6 . The activities are shown in relation to the $\mathrm{Na}, \mathrm{K}$ mode, which was $E_{\mathrm{A}}=1960 \mu \mathrm{mol}$ of $\mathrm{P}_{\mathrm{i}}$ (mg of protein) ${ }^{-1} \mathrm{~h}^{-1}$ at $37{ }^{\circ} \mathrm{C}$. Data were obtained as an average from at least nine independent measurements; errors are SEM. (B) $\mathrm{pH}$ dependence of the enzyme activity in the H-only mode of the Na,K-ATPase. The catalytic turnover rate was calculated as $v=$ $E_{\mathrm{A}} M(M=135000 \mathrm{~g} / \mathrm{mol})$. Filled circles represent the results obtained from inorganic phosphate release. For comparison the reciprocal value of the time period needed to consume $1 \mathrm{nmol}$ of ATP in RH421 experiments (as shown in Figure 3) is included (open circles). The experimental data were normalized to match with the catalytic turnover rate at $\mathrm{pH} 7.5$. The reciprocal of time is a rate, too, and the data were scaled to match the enzyme activity at $\mathrm{pH}$ 7.2. The $\mathrm{pH}$ dependence of both data sets could be fitted by the Hill function (eq 1) with the same $\mathrm{p} K$ of 6.4 .

for $\mathrm{H}^{+}$was found to be 6.4. The Hill coefficient of 2.5 indicates cooperative binding of more than $1 \mathrm{H}^{+}$. These results confirm previous findings that $\mathrm{H}^{+}$is able to replace $\mathrm{Na}^{+}$ions in ATP hydrolysis of the sodium pump $(5,12-15)$.

Detection of Electrogenic Charge Movements. In contrast to the determination of the enzyme activity which reports only details about the rate-limiting step(s) of the pump cycle, the application of electrochromic styryl dye RH421 is a potent tool to investigate partial reactions of the pump cycle of P-type ATPases. By this method it is possible to study and analyze first of all ionbinding and release steps of the pump cycle. Binding of cations in the binding sites which are located in the membrane domain of the sodium pump causes a decrease of the fluorescence intensity. RH421 (200 nM) and $9 \mu \mathrm{g}$ of protein were equilibrated in a cuvette filled with $1 \mathrm{~mL}$ of electrolyte of $25 \mathrm{mM}$ histidine, $0.5 \mathrm{mM}$ EDTA, and $5 \mathrm{mM} \mathrm{MgCl}_{2}$ at $\mathrm{pH} 7.15$ (and no $\mathrm{Na}^{+}$or $\mathrm{K}^{+}$). After a 

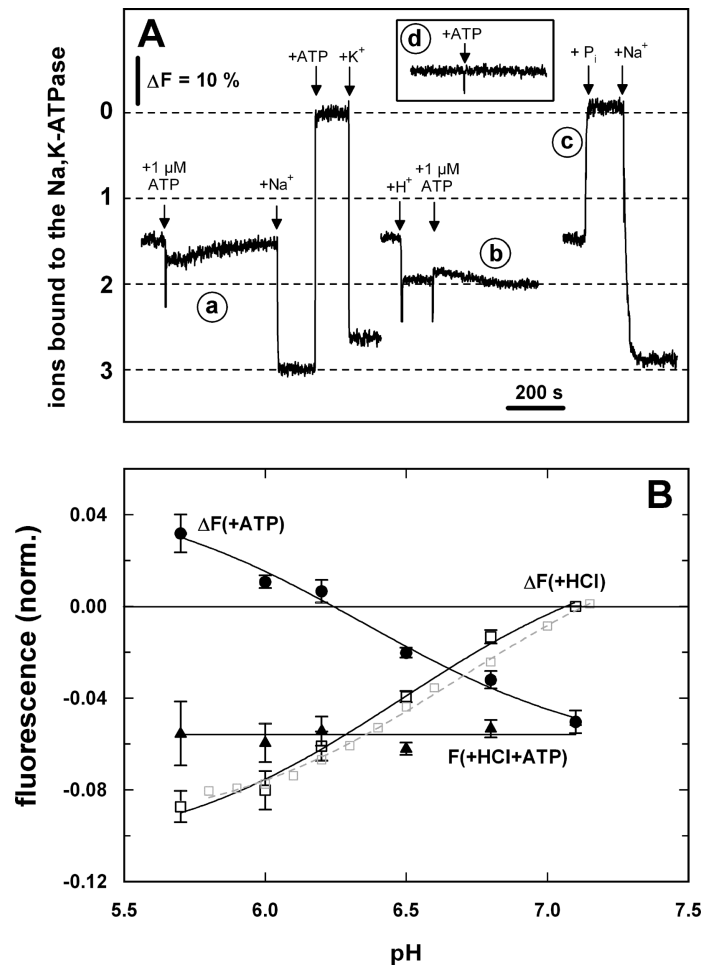

FIgURE 3: RH421 fluorescence of electrogenic actions of the Na,KATPase in the $\mathrm{H}$-only mode. (A) When in $\mathrm{Na}^{+}$- and $\mathrm{K}^{+}$-free buffer at $\mathrm{pH} 7.15$ a stable fluorescence level was obtained $1 \mathrm{nmol}$ of ATP ("+1 $\mu \mathrm{M}$ ATP") was added that induced a transient fluorescence decrease for about $400 \mathrm{~s}$ (trace a). The levels obtained upon addition of $50 \mathrm{mM} \mathrm{NaCl}$ ("+ $\mathrm{Na}^{+}$") and $200 \mu \mathrm{M}$ ATP ("+ATP") contain 3 $\mathrm{Na}^{+}$or no $\mathrm{Na}^{+}$, respectively, and may be used to calibrate the fluorescence levels in terms of the number of ions bound. At $\mathrm{pH}$ 7.15, before any substrate addition the $\mathrm{Na}, \mathrm{K}$-ATPases are in the state $\mathrm{H}_{x} \mathrm{E}_{1}$ with $x=1.4-1.5$. The presence of $0.1 \mathrm{mM}$ ouabain abolished any electrogenic response upon addition of ATP (trace $d$ in inset). When the $\mathrm{pH}$ was decreased to $\mathrm{pH} 6.0$, addition of $200 \mu \mathrm{M}$ ATP produced a transient fluorescence increase of shorter duration of about $200 \mathrm{~s}$ (trace b). In trace c levels with 0 and $3 \mathrm{Na}^{+}$ions bound were obtained by back-door phosphorylation with $500 \mu \mathrm{M} \mathrm{P}_{\mathrm{i}}$ to obtain state $\mathrm{P}-\mathrm{E}_{2}$ and by addition of $50 \mathrm{mM} \mathrm{NaCl}$ to force the pumps into state $\mathrm{Na}_{3} \mathrm{E}_{1}$, respectively. (B) $\mathrm{pH}$ dependence of the fluorescence responses after addition of hydrochloric acid, $\Delta F(+\mathrm{HCl})$, and ATP, $\Delta F(+\mathrm{ATP})$, and of the fluorescence level obtained immediately after addition of ATP, $F(+\mathrm{HCl}+\mathrm{ATP})$. The $\mathrm{HCl}$-induced fluorescence changes from experiments of the type shown in panel A, trace b (black open squares), are compared to $\mathrm{pH}$ titration experiments performed in the $\mathrm{E}_{1}$ conformation (gray open squares). The data were fitted with titration curves, and the fits produced $\mathrm{p} K$ of $6.5 \pm 0.1(\Delta F(+\mathrm{HCl}))$, and $6.4 \pm 0.1(\Delta F(+\mathrm{ATP}))$. In the case of the fluorescence level, $F(+\mathrm{HCl}+\mathrm{ATP})$, the line was drawn to indicate the average value of -0.056 . Error bars represent the SEM.

constant fluorescence level was obtained, which represents the reference level, $F_{0}$, different substrate additions were performed. When $1 \mu \mathrm{M} \mathrm{MgATP}$ was added, an immediate drop of the fluorescence amplitude of $\sim 5 \%$ was observed (Figure $3 \mathrm{~A}$, trace a). Such a decrease indicates additional binding of positive charge inside the membrane domain of the Na,K-ATPase, which has to be a proton in the absence of other monovalent cations. This state was, however, only transient and ran off after about $300 \mathrm{~s}$. The transient behavior can be explained by pump-facilitated consumption of the low amount of ATP. Subsequently, $50 \mathrm{mM} \mathrm{NaCl}$ was added, which leads to a transition of all pumps into the state with $3 \mathrm{Na}^{+}$bound, $\mathrm{Na}_{3} \mathrm{E}_{1}$. When $200 \mu \mathrm{M}$ ATP was added next, the pump proceeds to the $\mathrm{P}-\mathrm{E}_{2}$ conformation in which more than $90 \%$ of all $\mathrm{Na}^{+}$are released from their binding sites on the extracellular face due to the low binding affinity. In the presence of $\mathrm{Na}^{+}$and ATP and at $\mathrm{pH} 7.2$ the pumps are able to run through pump cycles with transporting stoichiometries of $3 \mathrm{Na}^{+} / 2 \mathrm{Na}^{+} /$ 1 ATP or $3 \mathrm{Na}^{+} / 2 \mathrm{H}^{+} / 1$ ATP. The back-reaction from P-E $\mathrm{E}_{2}$ to $\mathrm{E}_{1}$ is, however, strongly rate limited. Therefore, most of the pumps are accumulated in the $\mathrm{P}-\mathrm{E}_{2}$ state with the observed high fluorescence level. Addition of $20 \mathrm{mM} \mathrm{KCl}$ allows the $\mathrm{Na}, \mathrm{K}$ ATPase to run continuously through the physiological pump cycle with a $3 \mathrm{Na}^{+} / 2 \mathrm{~K}^{+} / 1$ ATP stoichiometry, and the resulting fluorescence level reflects an average of the levels of all states occupied, mainly $\left(\mathrm{Na}_{3}\right) \mathrm{E}_{1}-\mathrm{P}$ and $\mathrm{E}_{2}\left(\mathrm{~K}_{2}\right)$, which precede the two slowest reaction steps of the pump cycle. Since the electrochromic effect of RH421 is linear in the number of charges bound in the membrane domain (19), and the states $\mathrm{Na}_{3} \mathrm{E}_{1}$ and $\mathrm{P}-\mathrm{E}_{2}$ have defined numbers of ions bound, it is possible to estimate from the fluorescence levels the number of ions bound to the pump (Figure 3A). Under the chosen experimental condition of trace a, $1 \mu \mathrm{M}$ ATP corresponds initially to about 20 ATP molecules per ATPase present. As control, to verify that the effect was caused by the Na,K-ATPase, the experiment was repeated in the presence of $0.1 \mathrm{mM}$ ouabain. At this inhibitor concentration the pump is completely blocked, and the addition of $1 \mu \mathrm{M} \mathrm{MgATP}$ produced no fluorescence change as expected (Figure 3A, trace $\mathrm{d}$ in the inset). In a third experiment buffer $\mathrm{pH}$ was lowered to 6.0 by adding an adequate aliquot of $\mathrm{HCl}$ before $1 \mu \mathrm{M} \mathrm{MgATP}$ was mixed into the cuvette (Figure 3A, trace b). The $\mathrm{pH}$ change caused a fluorescence drop to the level corresponding to an occupation with $2 \mathrm{H}^{+}$, in agreement with the equilibrium $\mathrm{pH}$ titration shown below (Figure 3B). At $\mathrm{pH} 6$, the addition of $1 \mu \mathrm{M} \mathrm{MgATP}$ produced a small positive fluorescence transient which lasted a shorter period than at $\mathrm{pH} 7.15$ before the fluorescence signal returned to the level before the ATP addition. A quantitative analysis of the time periods as function of $\mathrm{pH}$ is included in Figure 2B. The faster return to the level before ATP indicates a faster depletion of ATP caused by a higher hydrolysis rate. When the Na,K-ATPase was phosphorylated by inorganic phosphate, $\mathrm{P}_{\mathrm{i}}$, in the absence of $\mathrm{Na}^{+}$and $\mathrm{K}^{+}$(trace $\mathrm{c}$ ), the transition to state $\mathrm{P}-\mathrm{E}_{2}$ with no ions bound (see below) is in good agreement with the level of trace a. When subsequently $50 \mathrm{mM} \mathrm{NaCl}$ was added, an extended (linear) reaction sequence of the Post-Albers cycle becomes accessible, $\mathrm{P}-\mathrm{E}_{2} \leftrightarrow \mathrm{P}-\mathrm{E}_{2} \mathrm{X}_{2} \leftrightarrow \mathrm{E}_{2}\left(\mathrm{X}_{2}\right) \leftrightarrow \mathrm{X}_{2} \mathrm{E}_{1} \leftrightarrow$ $\mathrm{Na}_{3} \mathrm{E}_{1}$, in which $\mathrm{X}$ stands for $\mathrm{Na}^{+}$or $\mathrm{H}^{+}$. Due to the high $\mathrm{Na}^{+}-$ binding affinity in the $\mathrm{E}_{1}$ conformation the appearing new equilibrium state is one shifted (quantitatively) to the $\mathrm{Na}_{3} \mathrm{E}_{1}$ state, as can be deduced from the low fluorescence level of trace $\mathrm{c}$. This transition has a time constant of $\sim 25 \mathrm{~s}$ and is more than 10 -fold slower than the transition upon addition of $\mathrm{K}^{+}$in the presence of ATP (trace a).

Experiments as shown in Figure 3A, trace a, were repeated at various $\mathrm{pHs}$ between 5.7 and 7.2. The duration of the transient, i.e., the time until the fluorescence level returned to its initial value (before ATP was added), was determined. It reports how much time is needed to hydrolyze the amount of ATP added. The reciprocal value of this time interval is calculated, and this quantity is proportional to a kind of averaged pump rate. Therefore, it may be compared to the catalytic turnover rate obtained from ATPase activity and with appropriate scaling showed a reasonable agreement between both experimental approaches (Figure 2B). This agreement supports the concept that the fluorescence changes in the RH421 experiments reflect electrogenic partial reactions related to the ATP-induced activity of the Na,K-ATPase also in the absence of $\mathrm{Na}^{+}$and $\mathrm{K}^{+}$ions. 


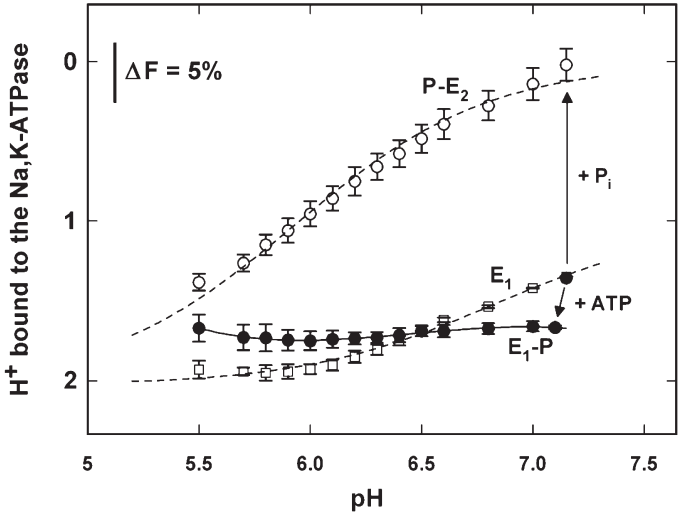

FIGURE 4: pH dependence of the fluorescence level of the $\mathrm{Na}, \mathrm{K}$ ATPase in the absence of $\mathrm{Na}^{+}$and $\mathrm{K}^{+}$in the $\mathrm{E}_{1}$ conformation (open squares), in the P-E 2 conformation (open circles), and of the ATPinduced state (solid circles). $\mathrm{pH}$ titrations were performed in buffer containing $25 \mathrm{mM}$ histidine, $0.5 \mathrm{mM}$ EDTA, and $5 \mathrm{mM} \mathrm{MgCl}_{2}\left(\mathrm{E}_{1}\right)$ after addition of $0.5 \mathrm{mM}$ inorganic phosphate $\left(\mathrm{P}-\mathrm{E}_{2}\right)$ or after addition of $0.5 \mathrm{mM} \mathrm{MgATP}$ (ATP-induced state). The fluorescence levels have been recalibrated in terms of binding-site occupation by $\mathrm{H}^{+}$ according to Figure 3A.

The normalized RH421 fluorescence changes of experiments as shown in Figure 3A were analyzed and plotted against the buffer $\mathrm{pH}$. The results are shown in Figure 3B. All experiments were started in buffer of $25 \mathrm{mM}$ histidine, $5 \mathrm{mM} \mathrm{MgCl} 2,0.14 \mathrm{mM}$ EDTA, pH 7.2, $200 \mathrm{nM} \mathrm{RH} 421$, and $9 \mu \mathrm{g}$ of protein. When $\mathrm{HCl}$ was added to reduce $\mathrm{pH}$, an instant fluorescence drop was detected. The resulting $\mathrm{pH}$ in the buffer was measured by a $\mathrm{pH}$ microelectrode. The $\mathrm{pH}$ dependence of the fluorescence decrease, $\Delta F(+\mathrm{HCl})$ (black open squares), could be fitted by a titration curve with a $\mathrm{p} K$ of $6.5 \pm 0.1$. The fluorescence decrease upon $\mathrm{HCl}$ addition from different experiments of the type shown in Figure $3 \mathrm{~A}$, trace $\mathrm{b}$, was compared to the fluorescence decrease determined from $\mathrm{pH}$ titration experiments (gray open squares), which were performed as described below (Figure 4), and reasonable agreement was found; the corresponding $\mathrm{p} K$ was 6.6 likewise. The next step in the experiments, addition of $1 \mu \mathrm{M} \mathrm{MgATP}$, led to a fluorescence decrease at $\mathrm{pH}>6.25$ and to a fluorescence increase at $\mathrm{pH}<6.25$ (solid circles). The $\mathrm{pH}$ dependence of the ATP-induced fluorescence change, $\Delta F(+\mathrm{ATP})$, could be fitted also by a titration curve with $\mathrm{p} K 6.4 \pm 0.1$ The third fluorescence parameter determined from the experiments was the fluorescence level obtained immediately after addition of MgATP before it ceased due to ATP consumption, $F(+\mathrm{HCl}+\mathrm{ATP})$. In the whole $\mathrm{pH}$ range between $\mathrm{pH} 7.2$ and $\mathrm{pH} 5.7$ no significant $\mathrm{pH}$ dependence was found with an average level of $-5.6 \pm 0.1 \%$, with respect to the initial level at $\mathrm{pH} 7.6$ in the absence of ATP (solid triangles). This finding indicates that the ATP-induced stationary state has on the average less than two protons bound (compare Figure 3A).

To test the $\mathrm{pH}$ dependence of the RH421 fluorescence in the stationary state which is obtained after addition of $\mathrm{MgATP}$, a series of $\mathrm{pH}$ titration experiments were performed under three different conditions (Figure 4). All experiments were started in buffer containing $25 \mathrm{mM}$ histidine, $0.5 \mathrm{mM}$ EDTA, $5 \mathrm{mM}$ $\mathrm{MgCl}_{2}, \mathrm{pH} 7.15,200 \mathrm{nM}$ RH421, and $9 \mu \mathrm{g}$ of protein. First, $\mathrm{pH}$ titrations were performed in $\mathrm{E}_{1}$ by additions of small aliquots of $\mathrm{HCl}$ after the initial $F_{0}$ level was reached (open squares). At low pH $(<6.0)$ the fluorescence became constant at a level of $-8 \%$, which represents states with $2 \mathrm{H}^{+}$bound to the binding sites, $\mathrm{H}_{2} \mathrm{E}_{1}$ and $\mathrm{E}_{2}\left(\mathrm{H}_{2}\right)(7,8)$. Second, the $\mathrm{Na}, \mathrm{K}$-ATPase was

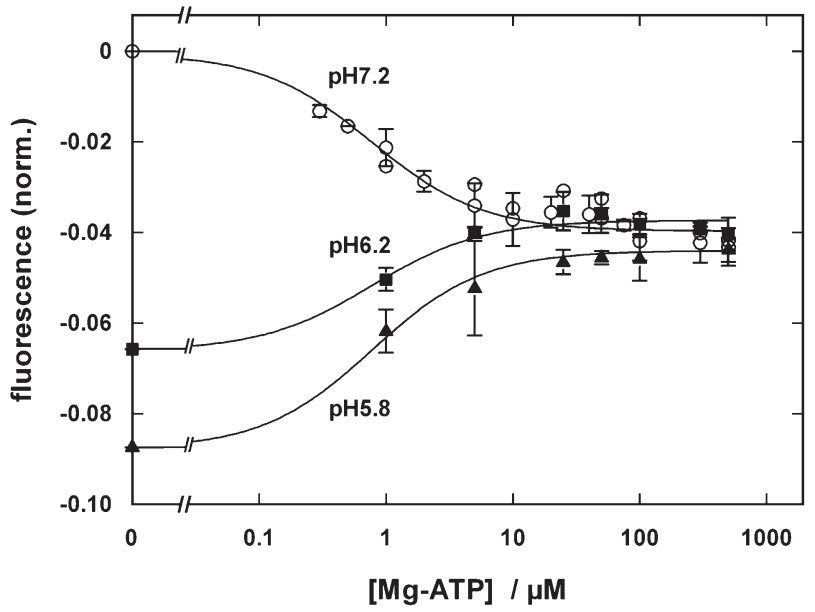

FIGURE 5: ATP-dependent RH421 fluorescence of the Na,K-ATPase in the absence of $\mathrm{Na}^{+}$and $\mathrm{K}^{+}$at three different $\mathrm{pH}$ values in buffer containing $25 \mathrm{mM}$ histidine, $0.5 \mathrm{mM}$ EDTA, and $5 \mathrm{mM}$ $\mathrm{MgCl}_{2}$. The concentration dependence can be fitted by a single binding isotherm (solid lines). All three sets of data were fitted simultaneously with an equilibrium dissociation constant of $K_{\mathrm{M}}=$ $0.78 \pm 0.14 \mu \mathrm{M}$.

phosphorylated by $0.5 \mathrm{mM}$ inorganic phosphate, $\mathrm{P}_{\mathrm{i}}$, in the absence of $\mathrm{Na}^{+}$and ATP, and the so-called back-door phosphorylation step occurred with two $\mathrm{H}^{+}$in the ion-binding sites, $\mathrm{E}_{2}\left(\mathrm{H}_{2}\right)+\mathrm{P}_{\mathrm{i}} \rightarrow \mathrm{P}_{-} \mathrm{E}_{2} \mathrm{H}_{2}$ (7). Since $\mathrm{H}^{+}$binding affinity is significantly lower in the $\mathrm{P}-\mathrm{E}_{2}$ conformation, both protons are (almost completely) released from the pump and a significant RH421 fluorescence increase is observed (open circles), and the obtained fluorescence level at $\mathrm{pH} 7.15$ is assigned to the $\mathrm{P}_{-} \mathrm{E}_{2}$ state with empty binding sites $\left(<0.1 \mathrm{H}^{+}\right)$, as shown in Figure 3A and proposed earlier (7). Both titrations provide reference levels with no or 2 ions bound and allow the calibration of fluorescence levels in terms of binding site occupation (similarly to Figure 3A). The third data set comprises $\mathrm{pH}$ titrations in the presence of (saturating) $0.5 \mathrm{mM}$ ATP. When $0.5 \mathrm{mM} \mathrm{MgATP}$ was added to the buffer, a small fluorescence decrease was observed to a level which indicates a state with 1.6-1.7 $\mathrm{H}^{+}$bound (solid circles). Since at $\mathrm{pH} 7.15$ the buffer capacity of $25 \mathrm{mM}$ histidine is not high enough, the (acidic) ATP solution reduced the $\mathrm{pH}$ slightly to 7.1. Subsequently, small aliquots of $\mathrm{HCl}$ were applied to decrease the $\mathrm{pH}$ stepwise to 5.5. As observed in the experiments in which ATP was added in low concentrations (Figure 3B), the fluorescence level remained almost constant in the whole $\mathrm{pH}$ range; only at lower $\mathrm{pH}(<5.8)$ was a slight fluorescence increase observed. It has to be noted that the open circles in Figure 4 illustrate a titration of the externally accessible binding sites when cycling is not possible, whereas the filled circles indicate an average proton occupancy under conditions in which every state in the cycle is being visited at some finite frequency. The low level obtained after enzyme phosphorylation by ATP indicates, however, that an actual rate-limiting step in that cycle must control proton release to yield the empty $\mathrm{P}-\mathrm{E}_{2}$ state, such that at all $\mathrm{pH}$ levels the pumps tend to accumulate in a proton-bound state, e.g., $\left(\mathrm{H}_{2}\right) \mathrm{E}_{1}-\mathrm{P}$.

To gain more information on the $\mathrm{pH}$-dependent tendency of the fluorescence change upon addition of MgATP (Figure 3A), the ATP-concentration dependence of the fluorescence change was studied at different $\mathrm{pHs}$ between 5.8 and 7.2. The results are compiled in Figure 5. In $25 \mathrm{mM}$ histidine, $5 \mathrm{mM} \mathrm{MgCl} 2,0.5 \mathrm{mM}$ EDTA, pH 7.2, $200 \mathrm{nM} \mathrm{RH421,} \mathrm{and} 9 \mu \mathrm{g} / \mathrm{mL}$ protein were 
equilibrated. The respective stationary fluorescence level, $F_{0}$, was used as reference to normalize the fluorescence signals. If required, buffer $\mathrm{pH}$ was adjusted to $\mathrm{pH} 6.2$ or 5.8 by addition of small amounts of $\mathrm{HCl}$ after obtaining the initial stable fluorescence level. Then aliquots of MgATP were added to induce the fluorescence change for a specific ATP concentration in the range from $0.3 \mu \mathrm{M}$ up to $1 \mathrm{mM}$. At low ATP concentrations fluorescence transients were observed as shown in Figure 3A. In these cases the initial maximum fluorescence change was taken and plotted against the $\mathrm{MgATP}$ concentration in Figure 5. At pH 7.2 addition of ATP led to a fluorescence decrease of $\sim 4 \%$ at saturating ATP concentrations. The experiments were repeated at $\mathrm{pH} 6.2$ and 5.8. At these $\mathrm{pH}$ values the fluorescence levels increased with ATP and reached saturating fluorescence levels similar to that at $\mathrm{pH}$ 7.2. The concentration dependence was analyzed to obtain information on the binding kinetics. Fits of the data with simple Michaelis-Menten-type binding kinetics can be seen as lines in Figure 5. It was possible to obtain a satisfying fit when the data at all three buffer $\mathrm{pH}$ values were fitted simultaneously with the same equilibrium dissociation constants of $K_{\mathrm{M}}=0.78 \pm 0.14 \mu \mathrm{M}$ as shown in Figure 5 .

This number may be compared with the results from the analysis of rabbit kidney $\mathrm{Na}, \mathrm{K}-\mathrm{ATPase}$ reconstituted in DOPC vesicles in the presence of cytoplasmic $\mathrm{Na}^{+}$and extracellular $\mathrm{K}^{+}$. Under this condition two equilibrium dissociation constants were determined for ATP binding, $K_{\mathrm{M}, 1}=0.06 \mu \mathrm{M}$ and $K_{\mathrm{M}, 2}=13 \mu \mathrm{M}$ (29). The high ATP-binding affinity, $K_{\mathrm{M}, 1}$, has been assigned to ATP binding in the $\mathrm{E}_{1}$ conformation, while the low affinity has been related to ATP binding in the $\mathrm{E}_{2}$ conformation, $\mathrm{E}_{2}\left(\mathrm{~K}_{2}\right)+\mathrm{ATP} \rightarrow \mathrm{ATP} \cdot \mathrm{E}_{2}\left(\mathrm{~K}_{2}\right)$. The $K_{\mathrm{M}}$ value determined in the $\mathrm{H}$-only mode is a factor 13 higher than when also $\mathrm{Na}^{+}$was present and a factor 17 smaller than that of ATP binding to the $\mathrm{E}_{2}$ conformation. We propose that the observed apparent ATPbinding affinity has to be assigned to the reaction sequence in the $\mathrm{E}_{1}$ conformation, $\mathrm{H}_{2} \mathrm{E}_{1}+\mathrm{ATP} \rightarrow \mathrm{H}_{2} \mathrm{E}_{1} \cdot \mathrm{ATP} \rightarrow\left(\mathrm{H}_{2}\right) \mathrm{E}_{1}-\mathrm{P}$. When compared to the $\mathrm{Na}^{+}$-transporting pump mode, the apparent shift of $K_{\mathrm{M}}$ to a higher value is caused by the fact that in the presence of only $2 \mathrm{H}^{+}$in the binding sites instead of $3 \mathrm{Na}^{+}$the cytoplasmic domains of the $\mathrm{Na}, \mathrm{K}-\mathrm{ATPa}$ a are maintained in a conformational arrangement that allows only a less effective ATP binding and enzyme phosphorylation.

Electrogenicity of the Pump Currents. Information on the overall electrogenicity of the $\mathrm{Na}, \mathrm{K}-\mathrm{ATP}$ ase in the $\mathrm{Na}^{+}$- and $\mathrm{K}^{+}$free pump mode can be obtained when the enzyme is reconstituted in vesicles. Proteoliposomes were prepared as described in the Materials and Methods section. A small amount of $\left(\mathrm{Na}^{+}\right.$free) vesicles $(0.42 \mu \mathrm{g} / \mathrm{mL}$ protein) and $95 \mathrm{nM}$ oxonol VI were equilibrated in $1 \mathrm{~mL}$ of electrolyte $(25 \mathrm{mM}$ histidine, $0.5 \mathrm{mM}$ EDTA, $5 \mathrm{mM} \mathrm{MgCl} 2,140 \mathrm{mM}$ choline chloride, $\mathrm{pH} 7.3, T=$ $20^{\circ} \mathrm{C}$ ). After a stable fluorescence signal was obtained, $250 \mu \mathrm{M}$ MgATP was added, and the ATPases with the cytoplasmic side facing outside start to pump and build up an electric membrane potential that is monitored as increasing fluorescence signal. The results are shown in Figure 6. No significant fluorescence change was observed in the absence of $\mathrm{Na}^{+}$. This observation shows that no electric membrane potential was built up, and thus, no electrogenic pump activity has occurred. The experiment was repeated in buffer of the same composition at $\mathrm{pH}$ 6.0. Again, no membrane potential was built up.

Then the experiment was repeated in buffer containing $140 \mathrm{mM} \mathrm{NaCl}$ instead of choline chloride. Upon addition of $250 \mu \mathrm{M}$ MgATP a fast initial fluorescence step $(+7 \%)$ became visible

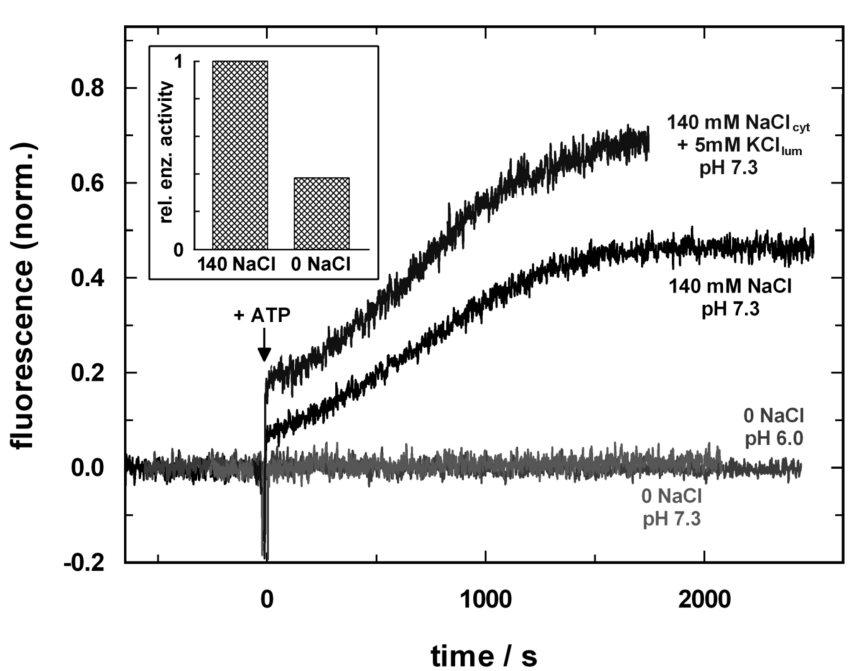

FIGURE 6: ATP-induced membrane potential changes generated by the Na,K-ATPase reconstituted in lipid vesicles. The membrane potential was detected by the fluorescent dye oxonol VI. In the presence of extravesicular (or cytoplasmic) $\mathrm{NaCl}$ electrogenic pump action was observed that produced a positive voltage inside the vesicles. In the absence of $\mathrm{Na}^{+}$ions no change of the membrane potential was observed at $\mathrm{pH} 7.3$ and also when $\mathrm{pH}$ was decreased to 6.0. An inactivation of the sodium pump can be excluded since the ATP-hydrolyzing enzyme activity under identical conditions was in the absence of $\mathrm{Na}^{+}$still $\sim 40 \%$ of the quantity in the presence of $140 \mathrm{mM} \mathrm{Na}^{+}$(inset). When the vesicles were filled with $5 \mathrm{mM} \mathrm{KCl}$, a larger initial pump activity facilitated by the physiological $\mathrm{Na}, \mathrm{K}$ mode was observed that switched to the slower Na-only after depletion of the internal $\mathrm{K}^{+}$.

upon addition of ATP. The origin of this step can be assigned to the first half-cycle of the Na,K-ATPase when $3 \mathrm{Na}^{+}$were transferred and released to the inner aqueous phase of the vesicles. According to Apell and Bersch (28) the detected initial fluorescence increase corresponds to a voltage increase, $\Delta V_{\mathrm{m}}=$ 6-7 $\mathrm{mV}$, which is generated by the transport of $\sim 10 \mathrm{Na}^{+}$ions. Since each Na,K-ATPase transfers $3 \mathrm{Na}^{+}$per ATP hydrolyzed, about $3-4$ active pumps are needed per vesicle to account for the fast initial fluorescence step.

Since $\mathrm{Na}^{+}$was present on the cytoplasmic but not on the extracellular side (which is the luminal side of the vesicles), the second half-cycle of the pump, in which protons are moved out of the vesicles, is rate-limiting due to the low affinity of $\mathrm{H}^{+}$in the $\mathrm{P}-\mathrm{E}_{2}$ conformation. Therefore, the pumps switched immediately to a slower mode after the first three $\mathrm{Na}^{+}$ions were released, and the electric membrane potential was built up with slower speed until a stationary voltage was reached. This occurred when the pump current matched the leak current of the vesicles (after $t>1500 \mathrm{~s}$ ).

A possible alternative explanation for the absence of an electrogenic activity in the $\mathrm{Na}^{+}$-free choline chloride buffer would be that the pumps reconstituted in vesicles are inactive in the absence of $\mathrm{Na}^{+}$. Therefore, the enzyme activity of the reconstituted $\mathrm{Na}, \mathrm{K}-\mathrm{ATPase}$ was determined by the malachite green assay in the buffers used in the oxonol experiments. The results, averaged from experiments with three different vesicle preparations, are shown in the inset in Figure 6. It has to be concluded that the enzyme was active in both buffers, but in the absence of $\mathrm{NaCl}$ no electrogenic transport occurred. The enzyme activity of the Na,K-ATPase reconstituted in DOPC vesicles was $128 \mu \mathrm{mol}$ of $\mathrm{P}_{\mathrm{i}} \mathrm{mg}^{-1} \mathrm{~h}^{-1}$ in the presence and $52.2 \mu \mathrm{mol}_{\text {of }} \mathrm{P}_{\mathrm{i}} \mathrm{mg}^{-1} \mathrm{~h}^{-1}$ in the absence of $\mathrm{NaCl}$. 


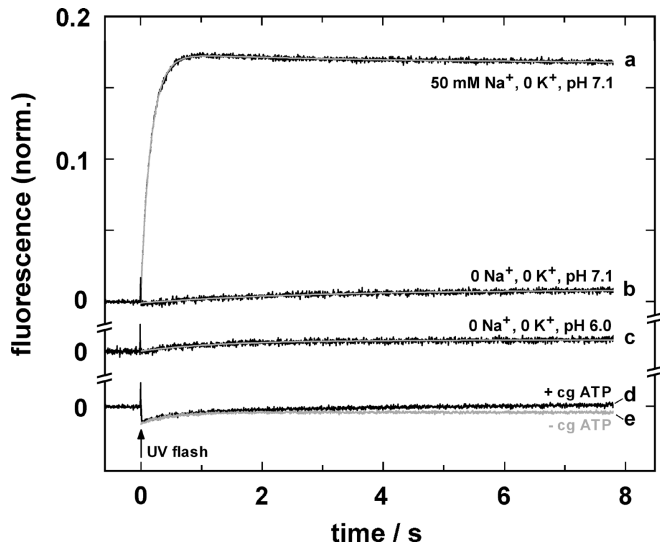

FIGURE 7: Time-resolved RH421 fluorescence responses of the Na, $\mathrm{K}$-ATPase upon an ATP-concentration jump from 0 to $10 \mu \mathrm{M}$. The $\mathrm{Na}, \mathrm{K}$-ATPase-containing membrane fragments were added to buffer containing either $50 \mathrm{mM} \mathrm{NaCl}$ to allow the Na-transporting mode or no $\mathrm{Na}^{+}$and no $\mathrm{K}^{+}$ions to force the pumps into the $\mathrm{H}$-only mode. A fast ATP-concentration jump was performed by photo release of ATP from NPE-caged ATP using an UV-laser flash. The fluorescence is normalized to the level before the release of ATP. After the flash artifact (at $t=0$ ) the time course could be fitted by the sum of two exponentials (Na-transporting mode, trace a) or by a single exponential (H-only mode, traces $\mathrm{b}$ and $\mathrm{c})$ indicated by the gray lines. Traces $\mathrm{b}$ and $\mathrm{c}$ are the difference signals between experiments with and without caged ATP as shown in traces d and e, respectively.

In a set of control experiments vesicles produced at $\mathrm{pH} 7.3$ were equilibrated overnight in buffer containing $140 \mathrm{mM}$ choline chloride and $5 \mathrm{mM} \mathrm{KCl}$. When thereafter oxonol VI experiments were performed in $\mathrm{Na}^{+}$- and $\mathrm{K}^{+}$-free buffer, addition of $250 \mu \mathrm{M}$ MgATP induced the H,K mode of the pump. This produced, however, again no membrane potential (not shown). In the presence of $140 \mathrm{mM} \mathrm{NaCl}$, the initial fast fluorescence step is significantly increased when compared to the experiment without $\mathrm{K}^{+}$(Figure 6). This finding indicates that the pumps are able to perform the physiological $\mathrm{Na}, \mathrm{K}$ mode until the luminal $\mathrm{K}^{+}$ concentration is depleted; then the pumps switch to the $\mathrm{Na}^{+}$-only mode. The amount of $\mathrm{K}^{+}$ions inside can be estimated from the known vesicle dimensions with a radius of $45 \mathrm{~nm}$ (28). At a $\mathrm{K}^{+}$ concentration of $5 \mathrm{mM}$ the number of $\mathrm{K}^{+}$ions in a vesicle is $\sim 1140$. This means that in the presence of a three active ion pumps per vesicle the pumps have to switch to the slower $\mathrm{Na}$-only mode within a few seconds. This estimate is in agreement with the observed transition from the steep initial slope to the slower further increase to the steady state.

Time-Resolved ATP-Concentration Jump Experiments. To study the ATP-induced partial reaction of the pump cycle, experiments with caged ATP were performed. The buffer consisted of $25 \mathrm{mM}$ histidine, $0.5 \mathrm{mM}$ EDTA, and $5 \mathrm{mM} \mathrm{MgCl}_{2}, \mathrm{pH}$ 7.1. To this solution were added $200 \mathrm{nM} \mathrm{RH} 421,100 \mu \mathrm{M}$ caged ATP, and $24 \mu \mathrm{g} / \mathrm{mL} \mathrm{Na}, \mathrm{K}-\mathrm{ATP}$ ase. After equilibration at $20^{\circ} \mathrm{C}$ about $10 \mu \mathrm{M}$ ATP was released by an UV-laser flash. The yield of $10 \%$ ATP released was determined by a firefly luciferase assay. ATP-concentration jump experiments were performed in the absence and presence of $\mathrm{NaCl}$, and the fluorescence change upon release of ATP was recorded for about $8 \mathrm{~s}$. To increase the signalto-noise ratio, three to five identical experiments were averaged. The result of three sets of experiments, at $\mathrm{pH} 7.1$ with and without $50 \mathrm{mM} \mathrm{Na}{ }^{+}$present and at $\mathrm{pH} 6.0$ without $\mathrm{Na}^{+}$, are shown in Figure 7. In the presence of $50 \mathrm{mM} \mathrm{NaCl}$ a fluorescence increase was observed that can be fitted by the sum of two exponential functions (gray line), a fast rising phase with a time constant $\tau_{1}=170 \pm 1 \mathrm{~ms}$ and an amplitude of $\Delta F_{1}=0.173 \pm$ 0.001 , followed by a small falling phase $\left(\tau_{2}=3.4 \pm 0.2 \mathrm{~s}\right.$, $\left.\Delta F_{2}=-0.007 \pm 0.001\right)$. This behavior is in agreement with previously published experiments, and by their detailed analysis it was determined that the rate-limiting step of the faster phase of this partial reaction is the conformation-transition step, $\left(\mathrm{Na}_{3}\right) \mathrm{E}_{1}-\mathrm{P} \rightarrow \mathrm{P}-\mathrm{E}_{2} \mathrm{Na}_{3}$ (17). The observed fluorescence increase is produced by the subsequent rapid electrogenic release of the $3 \mathrm{Na}^{+}$ions to the extracellular aqueous phase $(30,31)$.

Only a minor fluorescence increase was observed in the absence of $\mathrm{NaCl}$. In traces $\mathrm{d}$ and e of Figure 7 the time courses of the UV-flash-induced fluorescence signals of two experiments are overlaid, one with $100 \mu \mathrm{M}$ caged ATP (trace d) and one without (trace e). Obviously, the initial fast fluorescence decrease of $\sim 1 \%$ is caused by a UV-flash-induced artifact, as has been observed before (32). The difference of both signals is significant and represents the pump-specific activity; it is shown as trace $b$. The time course could be fitted by a single exponential with $\tau=$ $1.9 \pm 0.2 \mathrm{~s}, \Delta F=0.006 \pm 0.001$ at $\mathrm{pH} 7.1$. The experiments were repeated at $\mathrm{pH} 6.0$ with $\tau=1.36 \pm 0.05 \mathrm{~s}, \Delta F=0.008 \pm 0.001$ (trace c). When the EDTA concentration was reduced to $0.1 \mathrm{mM}$, a $\mathrm{pH}$ of 7.4 was obtained in the buffer, and under this condition no significant different fluorescence signal was found, $\tau=2.6 \pm$ $0.1 \mathrm{~s}, \Delta F=0.009 \pm 0.001$ (data not shown).

\section{DISCUSSION}

The stoichiometry of $3 \mathrm{Na}^{+} / 2 \mathrm{~K} / 1$ ATP turned out to be a convenient adaptation to meet the metabolic needs of animal cells. The higher stoichiometry for $\mathrm{Na}^{+}$is appropriate despite the significantly higher leak membrane permeability of $\mathrm{K}^{+}$ions since the pronounced electrochemical potential gradient for $\mathrm{Na}^{+}$is utilized by numerous $\mathrm{Na}^{+}$-coupled cotransporters and antiporters, such as $\mathrm{Na}^{+}$-sugar, $\mathrm{Na}^{+}-$amino acid, and $\mathrm{Na}^{+}-$phosphate cotransporters, or the $\mathrm{Na}^{+}, \mathrm{Ca}^{2+}$ antiporter. Therefore, the structural constraints of the Na,K-ATPase are optimized to ensure the known $\mathrm{Na}^{+}$stoichiometry and to prevent effectively energy dissipation by a slippage of the ion pump under physiological conditions. This is assured on the one hand by the presence of occluded states in the process of ion translocation (33) and on the other hand by implementation of a trigger mechanism that ensures enzyme phosphorylation only after $3 \mathrm{Na}^{+}$ions are bound (9). Such constraints are, however, never perfectly implemented in real proteins and, therefore, it is possible to find conditions in which they are overcome. The experiments presented here are an example for such a violation of the strict mechanism as represented by the Post-Albers pump cycle (Figure 1).

ATP Hydrolysis and Ion Transport. The occurrence of the ATP-hydrolyzing enzyme activity in the absence of $\mathrm{Na}^{+}$and $\mathrm{K}^{+}$, which can be inhibited by ouabain, indicates that a $\mathrm{Na}, \mathrm{K}$ ATPase specific activity exists. In the absence of $\mathrm{Na}^{+}$and $\mathrm{K}^{+}$ the only other monovalent cation present that can bind to the ion sites and may be transported is $\mathrm{H}^{+}$. At a physiological $\mathrm{pH}$ of 7.2 the residual enzyme activity is about $5 \%$ of the activity in the presence of saturating concentrations of $\mathrm{Na}^{+}$and $\mathrm{K}^{+}$(Figure 2A). The $\mathrm{pH}$ dependence of the enzyme activity (Figure 2B) demonstrates that higher $\mathrm{H}^{+}$concentrations enhance the activity. The observation that no significant enzyme activity was detectable in the presence of $20 \mathrm{mM} \mathrm{K}^{+}$(and $0 \mathrm{Na}^{+}$) at any $\mathrm{pH}$ was expected since it is known that under this condition the ion pumps are trapped mostly in the states $\mathrm{K}_{2} \mathrm{E}_{1}$ and $\mathrm{E}_{2}\left(\mathrm{~K}_{2}\right)$ due to the high affinity of the ion-binding sites for $\mathrm{K}^{+}(9)$. 


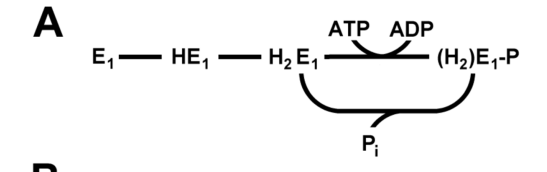

B

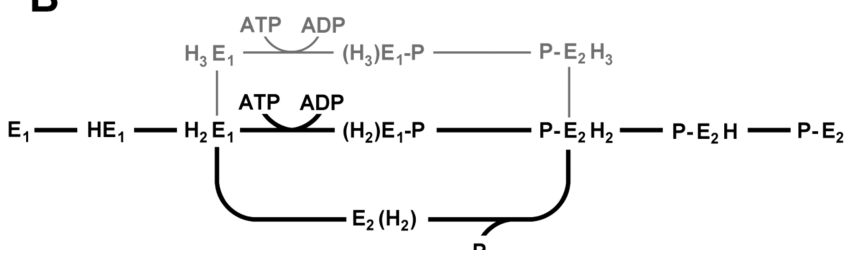

FIGURE 8: Reaction schemes describing possible pump cycles of the $\mathrm{Na}, \mathrm{K}-\mathrm{ATP}$ ase in the H-only mode. (A) In slippage mode, the enzyme hydrolyzes ATP and dissipates the free enthalpy without any transport of ions across the membrane. (B) ATP hydrolysis is accompanied by proton transfer across the membrane. In the ATP-driven halfcycle $\mathrm{H}^{+}$acts as congener of $\mathrm{Na}^{+}$, and two different stoichiometries are possible: (1) $3 \mathrm{H}^{+}$are bound (reaction pathway represented in gray) which would generate an overall electrogenic transport mode due to a $3 \mathrm{H}^{+} / 2 \mathrm{H}^{+}$stoichiometry, or (2) only $2 \mathrm{H}^{+}$are bound when the enzyme becomes phosphorylated (black representation). In this case an overall transport is electroneutral. The dephosphorylationdependent half-cycle, in which $\mathrm{H}^{+}$acts as congener of $\mathrm{K}^{+}$, has been well established in past studies. It is the same, independent of the transport stoichiometry of the ATP-driven half-cycle.

The difference in enzyme activity between the $\mathrm{Na}, \mathrm{K}$ mode and the mode when only $\mathrm{Na}^{+}$and $\mathrm{H}^{+}$are present must have its origin necessarily in modified kinetics of the reaction steps that compose the second half-cycle, $\mathrm{P}-\mathrm{E}_{2} \rightarrow \mathrm{E}_{1}$, in which $\mathrm{Na}^{+}$or $\mathrm{H}^{+}$replaces $\mathrm{K}^{+}$as congener. The replacement of $\mathrm{K}^{+}$by congeners led to a reduction of the enzyme activity to $40 \%$ compared to the $\mathrm{Na}, \mathrm{K}$ mode. This is a consequence of the fact (1) that the congeners bind to the Na,K-ATPase less strongly than $\mathrm{K}^{+}$at saturating concentrations and (2) that the congener-transporting partial reactions, e.g. $\mathrm{P}-\mathrm{E}_{2} \mathrm{H}_{2} \rightarrow \mathrm{E}_{2}\left(\mathrm{H}_{2}\right) \rightarrow \mathrm{ATP} \cdot \mathrm{E}_{2}\left(\mathrm{H}_{2}\right) \rightarrow \mathrm{H}_{2} \mathrm{E}_{1} \cdot \mathrm{ATP}$, have a reduced reaction rate. In contrast, the ATP-driven, $\mathrm{Na}^{+}$translocating forward half-cycle is the same in the presence or absence of $\mathrm{K}^{+}$.

When the Na-transporting mode (i.e., no $\mathrm{K}^{+}$present) is compared with the $\mathrm{H}$-only mode (i.e., no $\mathrm{Na}^{+}$, no $\mathrm{K}^{+}$), an 8-fold reduction in enzyme activity has been found at $\mathrm{pH} 7.2$ (Figure 2A). The most basic difference between both modes could be that the Na, K-ATPase does not transport protons in the ATP-driven half-cycle, and the observed ATP hydrolysis is caused by a kind of slippage reaction, an uncoupled enzyme activity in which the pumps run through a purely dissipative ATP-hydrolyzing cycle. This would lead to a reaction cycle in the form of scheme A shown in Figure 8. The observation that enzyme activity increased with decreasing $\mathrm{pH}$ (shown in Figure 2B) would be consistent with scheme A: higher $\mathrm{pH}$ leads to a higher population of state $\mathrm{E}_{1} \mathrm{H}_{2}$ and that promotes the reaction flux through the ATP-consuming reaction cycle.

Conclusive evidence that such a slippage reaction does not occur was obtained from experiments which demonstrate that a transition occurs from the initial $\mathrm{H}_{x} \mathrm{E}_{1}$ to a deoccluded $\mathrm{P}-\mathrm{E}_{2} \mathrm{H}_{y}$ state. This is confirmable, e.g., when the number of $\mathrm{H}^{+}$bound in $\mathrm{E}_{1}, x$, is different from the number of $\mathrm{H}^{+}$bound in $\mathrm{P}-\mathrm{E}_{2}, y$. In Figure 3 the fluorescence change upon addition of ATP is shown. At low pH $(<6.2)$ addition of ATP leads to a RH421 fluorescence increase. This observation indicates an ATP-dependent reallocation of the Na,K-ATPase to states of the pump cycle in which $\mathrm{H}^{+}$are released. Corresponding conclusions can be drawn also from the ATP-concentration-dependent fluorescence increase at $\mathrm{pH} 6.2$ and 5.8 in Figure 5. These findings, i.e., less $\mathrm{H}^{+}$bound at lower $\mathrm{pH}$, are, however, contradictory to an dissipative ATP hydrolysis as proposed in Figure 8A. Therefore, it can be excluded that the absence of $\mathrm{Na}^{+}$and $\mathrm{K}^{+}$ions provokes an uncoupling of enzyme activity and ion transport in the Na,K-ATPase.

Reaction Stoichiometry. In consequence, the next step was to test how $\mathrm{H}^{+}$replaces $\mathrm{Na}^{+}$in the ATP-driven half-cycle, and a solely proton-transporting Post-Albers-type pump cycle was proposed. An obvious version is shown in Figure 8B. The observed experimental differences between the pump mode when $\mathrm{Na}^{+}$is present and the H-only mode have to be caused by a different rate-limiting process in the forward half-cycle, $\left(x \mathrm{H}^{+}\right)_{\text {cyt }}+$ $\mathrm{E}_{1} \rightarrow \mathrm{P}-\mathrm{E}_{2}+\left(x \mathrm{H}^{+}\right)_{\text {ext }}$. To identify the modification(s) in this partial reaction, each single reaction step has to be scrutinized. This will be discussed below in the section on the Reaction Mechanism. As before, the stoichiometry has to be clarified, i.e., whether the number of protons transferred, $x$, is 2 or 3 . As can be seen from Figure 4 and from previously published data (8), protons interact with the ion-binding sites in both principal conformations, $\mathrm{E}_{1}$ and $\mathrm{P}-\mathrm{E}_{2}$, and maintain a dynamic and $\mathrm{pH}$-dependent equilibrium. The affinity of the ion-binding sites is different in both conformations, with a significantly higher proton affinity in the $\mathrm{E}_{1}$ conformation. At $\mathrm{pH} 7.2$, in the $\mathrm{E}_{1}$ conformation an average of $1.4 \mathrm{H}^{+}$are bound, while in the P- $\mathrm{E}_{2}$ conformation only $\sim 0.1 \mathrm{H}^{+}$will occupy the binding sites. These numbers were derived from the analysis of the fluorescence levels in Figure 3A. The linear relation between occupation of the binding sites and fluorescence levels is used to check whether the ATP-driven half-cycle was performed with 2 or $3 \mathrm{H}^{+}$bound, as is indicated by the black and gray reaction pathway in Figure 8B, respectively. A discrimination between both proposals is possible by two methods: one is the analysis of the time-resolved fluorescence signal in the ATP-concentration jump experiments, and the other is the overall electrogenicity of the complete pump cycle.

When ATP-concentration jump experiments were performed in the presence of $50 \mathrm{mM} \mathrm{NaCl}$, the ion pumps were accumulated initially almost quantitatively in the $\mathrm{Na}_{3} \mathrm{E}_{1}$ state. After the release of ATP the pumps perform a synchronized transition to the state $\mathrm{P}-\mathrm{E}_{2}$ with almost no ions $(<0.1)$ left in the binding sites $(34)$. The release of $3 \mathrm{Na}^{+}$ions is reflected by a fluorescence increase of $\sim 17 \%$ (Figure 7, trace a). When the same experiment was repeated without $\mathrm{NaCl}$ (all other conditions identical), the initial state, before phosphorylation, was $\mathrm{H}_{x} \mathrm{E}_{1}$ with $x \approx 1.4$ according to Figure 3A. The ATP-induced partial reaction produced a minor fluorescence increase of about $1 \%$ with a time constant of $1.3-2 \mathrm{~s}$ (Figure 7, traces b and c). Compared to the fluorescence change of $17 \%$ for the release of three elementary charges (trace a), a change of $1 \%$ corresponds to $\sim 0.18$ elementary charges. The fluorescence level of the resulting stationary state $(t>5 \mathrm{~s})$ corresponds, therefore, to an average occupation of the sites with about $\sim 1.2$ ions after the new steady state was attained. The most important information deducible from this monophasic time course is, however, that the reaction did not pass through a transient state with $3 \mathrm{H}^{+}$bound. Binding of an additional 1.6 protons to obtain the states with $3 \mathrm{H}^{+}$bound, $\mathrm{H}_{3} \mathrm{E}_{1}$ and $\left(\mathrm{H}_{3}\right) \mathrm{E}_{1}-\mathrm{P}$, would have produced in this setup a fluorescence decrease of $9 \%$ below the initial level, as can be estimated from the fluorescence changes of $17 \%$ observed for the release of $3 \mathrm{Na}^{+}$.

The second argument against a transport of $3 \mathrm{H}^{+}$ions in the ATP-driven half cycle is the results obtained from the studies with $\mathrm{Na}, \mathrm{K}-\mathrm{ATPase}$ in reconstituted lipid vesicles (Figure 6). On the one hand, in the absence of $\mathrm{Na}^{+}$and $\mathrm{K}^{+}$, an ATPase activity was 
found of about $40 \%$ of that in the presence of $\mathrm{Na}^{+}$, and an uncoupled slippage mode can be excluded (see above). On the other hand, no rise of an electric membrane potential across the vesicle membrane has been detected in the presence of protons only although ATP was hydrolyzed. This is a clear indication that no electrogenic overall transport has occurred. Therefore, in both half-cycles the same number of protons have to be transported in the $\mathrm{H}$-only mode of the $\mathrm{Na}, \mathrm{K}$-ATPase, and the stoichiometry has to be $2 \mathrm{H}^{+} / 2 \mathrm{H}^{+} / 1 \mathrm{ATP}$. A representation of this pump mode is shown in Figure 8B in black.

Reaction Mechanism. In the presence of $50 \mathrm{mM} \mathrm{Na}^{+}$the ATP-induced partial reaction, $\mathrm{Na}_{3} \mathrm{E}_{1} \rightarrow\left(\mathrm{Na}_{3}\right) \mathrm{E}_{1}-\mathrm{P} \rightarrow \mathrm{P}-\mathrm{E}_{2} \mathrm{Na}_{3}$ $\rightarrow \mathrm{P}-\mathrm{E}_{2}$, leads to a release of the three bound $\mathrm{Na}^{+}$ions which is accompanied by a significant increase of the RH421 fluorescence (Figure 7). Such an increase is not observed when only protons are present, although it would be expected if the partial reaction, $\mathrm{H}_{2} \mathrm{E}_{1}+\mathrm{ATP} \rightarrow\left(\mathrm{H}_{2}\right) \mathrm{E}_{1}-\mathrm{P} \rightarrow \mathrm{P}-\mathrm{E}_{2} \mathrm{H}_{2} \rightarrow \mathrm{P}-\mathrm{E}_{2}$, occurs. After a saturating amount of ATP was added, a fluorescence level was maintained in the new stationary state that corresponds to an averaged binding of between 1.6 and $1.7 \mathrm{H}^{+}$in the $\mathrm{pH}$ range between 7.1 and 5.5 (Figure 4). A reasonable explanation may be discussed on the basis of the reaction scheme of Figure 8B. Before addition of ATP the pumps are distributed between the states $\mathrm{E}_{1} \leftrightarrow \mathrm{HE}_{1} \leftrightarrow \mathrm{H}_{2} \mathrm{E}_{1}\left(\leftrightarrow \mathrm{E}_{2}\left(\mathrm{H}_{2}\right)\right)$. At $\mathrm{pH} 7.2$ a larger fraction of pumps is stabilized in $\mathrm{HE}_{1}$ and some in $\mathrm{H}_{2} \mathrm{E}_{1}$ (and $\mathrm{E}_{2}\left(\mathrm{H}_{2}\right)$ ) so that it sums up to an average of $\sim 1.4 \mathrm{H}^{+}$per pump as mentioned above. When ATP is added, enzyme phosphorylation, $\mathrm{H}_{2} \mathrm{E}_{1} \rightarrow\left(\mathrm{H}_{2}\right) \mathrm{E}_{1}$ $\mathrm{P}$, will occur and the pumps that proceed to the occluded state will drain (partially) the states with less than $2 \mathrm{H}^{+}$bound, $\mathrm{E}_{1}$ and $\mathrm{HE}_{1}$. This redistribution of states produces the observed fluorescence decrease. Since a considerable enzyme activity was found (Figures 2 and 6), the ion pumps will be able to proceed further to the subsequent reaction steps of the pump cycle. The first step is, according to the Post-Albers scheme, the conformation transition, $\left(\mathrm{H}_{2}\right) \mathrm{E}_{1}-\mathrm{P} \rightarrow \mathrm{P}-\mathrm{E}_{2} \mathrm{H}_{2}$. The reaction rate has to be, however, considerably lower than in the case of pumps with $3 \mathrm{Na}^{+}$ions bound. The rationale is as follows: due to the fact that the $\mathrm{H}^{+}$ binding affinity in the $\mathrm{P}-\mathrm{E}_{2}$ conformation is significantly lower than in $\mathrm{E}_{1}$, state $\mathrm{P}-\mathrm{E}_{2} \mathrm{H}_{2}$ is rapidly deprotonated at $\mathrm{pH}$ 7.2, and the pumps advance immediately to state $\mathrm{P}-\mathrm{E}_{2}$, which has the highest fluorescence level of all states in the pump cycle (Figure 4). The fact that only a low fluorescence signal, corresponding to $\sim 1.4-1.7 \mathrm{H}^{+}$bound, was detected upon phosphorylation supports the proposal that the conformation transition into the deoccluded $\mathrm{P}-\mathrm{E}_{2}$ state, $\left(\mathrm{H}_{2}\right) \mathrm{E}_{1}-\mathrm{P} \rightarrow$ $\mathrm{P}-\mathrm{E}_{2} \mathrm{H}_{2}$, has to be slow compared to the subsequent steps of the pump cycle, $\mathrm{P}-\mathrm{E}_{2} \mathrm{H}_{2} \rightarrow \mathrm{E}_{2}\left(\mathrm{H}_{2}\right) \rightarrow \mathrm{H}_{2} \mathrm{E}_{1}$. Therefore, the turnover back to $\left(\mathrm{H}_{2}\right) \mathrm{E}_{1}$ is fast enough to prevent a considerable accumulation of ion pumps in states with less than $1.4 \mathrm{H}^{+}$bound, especially in $\mathrm{P}-\mathrm{E}_{2}$.

On the other hand, if the phosphorylation step, $\mathrm{H}_{2} \mathrm{E}_{1} \cdot \mathrm{ATP} \rightarrow$ $\left(\mathrm{H}_{2}\right) \mathrm{E}_{1}-\mathrm{P}$, would be faster than the conformation transition, $\left(\mathrm{H}_{2}\right) \mathrm{E}_{1}-\mathrm{P} \rightarrow \mathrm{P}-\mathrm{E}_{2} \mathrm{H}_{2}$, then the accumulation of the pumps in the occluded state must become maximal; i.e., the fluorescence level after addition of ATP should decrease to the level with $2 \mathrm{H}^{+}$ bound, which it does not, especially at low $\mathrm{pH}$ at which $\mathrm{H}^{+}$ binding in $\mathrm{E}_{1}$ is already saturated (Figures $3 \mathrm{~A}$ and 4). This finding indicates that the enzyme phosphorylation, accompanied by proton occlusion, must be the slowest step in the half-cycle that normally transports $\mathrm{Na}^{+}$. In the presence of $\mathrm{Na}^{+}$the ratelimiting step is the conformation transition (17). The unoccupied $\mathrm{Na}^{+}$-specific third binding site in the membrane domain of the protein is proposed as evident reason for the dramatic reduction of the phosphorylation rate.

Mechanistic Implications. The results of preceding studies $(5,12-15)$ in which it was demonstrated that $\mathrm{H}^{+}$acts as $\mathrm{Na}^{+}$ congener in red blood cells or reconstituted membrane vesicles can all be understood by the ATP-driven $\mathrm{H}^{+}$transport as presented in Figure 8B in the "upper" half-cycle, and a "normal" $\mathrm{K}^{+}$or $\mathrm{Rb}^{+}$transport through the "lower" half-cycle of Figure 1. At sufficiently low $\mathrm{Na}^{+}$concentrations, i.e. significantly below the half-saturating $\mathrm{Na}^{+}$concentration in the $\mathrm{E}_{1}$ conformation, both the $\mathrm{Na}, \mathrm{K}$ and the $\mathrm{H}, \mathrm{K}$ mode coexist due to a reduced probability of the occupation of the binding sites with $\mathrm{Na}^{+}$ions which are then filled with $\mathrm{H}^{+}(8)$. This fact leads to an apparent reduced stoichiometric ratio of $\mathrm{Na} / \mathrm{K}$ as reported by Blostein and collaborators $(12,35)$. The ability of the Na,K-ATPase to pump $\mathrm{H}^{+}$out of a cell, although under unphysiological conditions only, resembles the mechanism of the $\mathrm{H}, \mathrm{K}-\mathrm{ATPa} e$ which is the closest related member of the Na,K-ATPase in the P-type ATPase family (36). The stoichiometry of the H,K-ATPase was shown to be $2 \mathrm{H}^{+} / 2 \mathrm{~K}^{+} / 1$ ATP (37), which makes this pump to an overall electroneutral transporter. This is precisely what was detected also for the Na,K-ATPase in the H-only (and $\mathrm{H}, \mathrm{K}$ ) mode. Some published studies with genetically engineered $\mathrm{Na}, \mathrm{K}$ ATPase can be seen as a kind of "missing link" between both ion pumps $(38,39)$. In these papers it was shown that the exchange of only a few amino acids in the ectodomain between TM3 and TM4 and three amino acids in TM4 against their H,K-ATPase counterparts produced a chimera that exhibits in the absence of $\mathrm{Na}^{+}$about $50 \%$ of the maximal enzyme activity at $\mathrm{pH} 6$.

From all of the findings presented above a simple proposal may be suggested to explain a development from the $\mathrm{Na}, \mathrm{K}$ ATPase to an H,K-ATPase. In a first step a sequence modification would be required as mentioned above $(38,39)$ that introduces a condition in which the third ion-binding site signals permanently to be occupied and thus enables immediate phosphorylation when the remaining two binding sites are engaged, as suggested recently (8). The second step needed would be a slight modification of the ion sites in the $\mathrm{E}_{1}$ conformation to make them more favorable for $\mathrm{H}^{+}$and unfavorable for $\mathrm{Na}^{+}$as is true in the case in the $\mathrm{P}-\mathrm{E}_{2}$ conformation of the unmodified $\mathrm{Na}, \mathrm{K}$-ATPase. The $\mathrm{K}^{+}$-translocating half-cycle needs no significant modification.

\section{ACKNOWLEDGMENT}

We thank Milena Roudna for excellent technical assistance.

\section{REFERENCES}

1. Post, R. L., Hegyvary, C., and Kume, S. (1972) Activation by adenosine triphosphate in the phosphorylation kinetics of sodium and potassium ion transport adenosine triphosphatase. J. Biol. Chem. 247, 6530-6540.

2. Albers, R. W. (1967) Biochemical aspects of active transport. Annu. Rev. Biochem. 36, 727-756.

3. Apell, H.-J. (2003) Structure-function relationship in P-type ATPases-a biophysical approach. Rev. Physiol. Biochem. Pharmacol. $150,1-35$.

4. Glynn, I. M. (1985) The $\mathrm{Na}^{+}, \mathrm{K}^{+}$-transporting adenosine triphosphatase, in Membrane Transport (Martonosi, A. N., Ed.) 2nd ed., pp 35-114, Plenum Press, New York.

5. Polvani, C., and Blostein, R. (1988) Protons as substitutes for sodium and potassium in the sodium pump reaction. J. Biol. Chem. 263, $16757-16763$

6. Goldshleger, R., Shahak, Y., and Karlish, S. J. D. (1990) Electrogenic and electroneutral transport modes of renal $\mathrm{Na} / \mathrm{K}$ ATPase reconstituted into proteoliposomes. J. Membr. Biol. 113, 139-154. 
7. Apell, H.-J., Roudna, M., Corrie, J. E., and Trentham, D. R. (1996) Kinetics of the phosphorylation of Na,K-ATPase by inorganic phosphate detected by a fluorescence method. Biochemistry 35, 10922-10930.

8. Apell, H.-J., and Diller, A. (2002) Do $\mathrm{H}^{+}$ions obscure electrogenic $\mathrm{Na}^{+}$and $\mathrm{K}^{+}$binding in the $\mathrm{E}_{1}$ state of the Na,K-ATPase? FEBS Lett. 532, 198-202.

9. Schneeberger, A., and Apell, H.-J. (1999) Ion selectivity of the cytoplasmic binding sites of the Na,K-ATPase: I. Sodium binding is associated with a conformational rearrangement. J. Membr. Biol. 168, 221-228.

10. Beauge, L. (1978) Activation by lithium ions of the inside sodium sites in $\left(\mathrm{Na}^{+}+\mathrm{K}^{+}\right)$-ATPase. Biochim. Biophys. Acta 527, 472-484.

11. Dunham, P. B., and Senyk, O. (1977) Lithium efflux through the $\mathrm{Na} / \mathrm{K}$ pump in human erythrocytes. Proc. Natl. Acad. Sci. U.S.A. 74, 3099-3103.

12. Blostein, R. (1985) Proton-activated rubidium transport catalyzed by the sodium pump. J. Biol. Chem. 260, 829-833.

13. Hara, Y., and Nakao, M. (1986) ATP-dependent proton uptake by proteoliposomes reconstituted with purified $\mathrm{Na}^{+}, \mathrm{K}^{+}$-ATPase. J. Biol. Chem. 261, 12655-12658.

14. Hara, Y., Yamada, J., and Nakao, M. (1986) Proton transport catalyzed by the sodium pump. Ouabain-sensitive ATPase activity and the phosphorylation of Na,K-ATPase in the absence of sodium ions. J. Biochem. 99, 531-539.

15. Polvani, C., and Blostein, R. (1988) Proton effects on the sodium pump. Prog. Clin. Biol. Res. 268A, 553-559.

16. Apell, H.-J. (2004) How do P-type ATPases transport ions? Bioelectrochemistry. 63, 149-156.

17. Heyse, S., Wuddel, I., Apell, H.-J., and Stürmer, W. (1994) Partial reactions of the $\mathrm{Na}, \mathrm{K}-\mathrm{ATPase}$ : determination of rate constants. J. Gen. Physiol. 104, 197-240.

18. Khalid, M., Fouassier, G., Apell, H. J., Cornelius, F., and Clarke, R. J. (2010) Interaction of ATP with the phosphoenzyme of the $\mathrm{Na}^{+}$, $\mathrm{K}^{+}$-ATPase. Biochemistry 49, 1248-1258.

19. Pedersen, M., Roudna, M., Beutner, S., Birmes, M., Reifers, B., Martin, H.-D., and Apell, H.-J. (2002) Detection of charge movements in ion pumps by a family of styryl dyes. J. Membr. Biol. 185, 221-236.

20. Visser, N. V., van Hoek, A., Visser, A. J., Frank, J., Apell, H.-J., and Clarke, R. J. (1995) Time-resolved fluorescence investigations of the interaction of the voltage-sensitive probe RH421 with lipid membranes and proteins. Biochemistry 34, 11777-11784.

21. Fedosova, N. U., Cornelius, F., and Klodos, I. (1998) E2P phosphoforms of $\mathrm{Na}, \mathrm{K}-\mathrm{ATPa}$. I. Comparison of phosphointermediates formed from ATP and Pi by their reactivity toward hydroxylamine and vanadate. Biochemistry 37, 13634-13642.

22. Jørgensen, P. L. (1974) Isolation of $\left(\mathrm{Na}^{+}+\mathrm{K}^{+}\right)$-ATPase. Methods Enzymol. 32, 277-290.

23. Schwartz, A. K., Nagano, M., Nakao, M., Lindenmayer, G. E., and Allen, J. C. (1971) The sodium- and potassium-activated adenosinetriphosphatase system. Methods Pharmacol. 1, 361-388.
24. Vagin, O., Denevich, S., Munson, K., and Sachs, G. (2002) SCH28080, a K ${ }^{+}$-competitive inhibitor of the gastric H,K-ATPase, binds near the M5-6 luminal loop, preventing $\mathrm{K}^{+}$access to the ion binding domain. Biochemistry 41, 12755-12762.

25. Witzke, A., Lindner, K., Munson, K., and Apell, H. J. (2010) Inhibition of the gastric H,K-ATPase by clotrimazole. Biochemistry 49, 4524-4532.

26. Stürmer, W., Apell, H.-J., Wuddel, I., and Läuger, P. (1989) Conformational transitions and change translocation by the $\mathrm{Na}, \mathrm{K}$ pump: comparison of optical and electrical transients elicited by ATPconcentration jumps. J. Membr. Biol. 110, 67-86.

27. Apell, H.-J., Marcus, M. M., Anner, B. M., Oetliker, H., and Läuger, P. (1985) Optical study of active ion transport in lipid vesicles containing reconstituted Na,K-ATPase. J. Membr. Biol. 85, 49-63.

28. Apell, H.-J., and Bersch, B. (1987) Oxonol VI as an optical indicator for membrane potentials in lipid vesicles. Biochim. Biophys. Acta 903, 480-494.

29. Apell, H.-J., Häring, V., and Roudna, M. (1990) Na,K-ATPase in artificial lipid vesicles. Comparison of $\mathrm{Na}, \mathrm{K}$ and Na-only pumping mode. Biochim. Biophys. Acta 1023, 81-90.

30. Wuddel, I., and Apell, H.-J. (1995) Electrogenicity of the sodium transport pathway in the Na,K-ATPase probed by charge-pulse experiments. Biophys. J. 69, 909-921.

31. Holmgren, M., Wagg, J., Bezanilla, F., Rakowski, R. F., de Weer, P., and Gadsby, D. C. (2000) Three distinct and sequential steps in the release of sodium ions by the $\mathrm{Na}^{+} / \mathrm{K}^{+}$-ATPase. Nature 403, 898-901.

32. Fibich, A., Janko, K., and Apell, H. J. (2007) Kinetics of proton binding to the sarcoplasmic reticulum Ca-ATPase in the $\mathrm{E}_{1}$ state. Biophys. J. 93, 3092-3104.

33. Glynn, I. M., and Karlish, S. J. (1990) Occluded cations in active transport. Annu. Rev. Biochem. 59, 171-205.

34. Stürmer, W., Bühler, R., Apell, H.-J., and Läuger, P. (1991) Charge translocation by the Na,K-pump: II. Ion binding and release at the extracellular face. J. Membr. Biol. 121, 163-176.

35. Blostein, R., and Polvani, C. (1991) Proton transport, charge transfer, and variable stoichiometry of the Na,K-ATPase. Soc. Gen. Physiol Ser. 46, 289-301.

36. Møller, J. V., Juul, B., and le Maire, M. (1996) Structural organization, ion transport, and energy transduction of P-type ATPases. Biochim. Biophys. Acta 1286, 1-51.

37. Rabon, E. C., McFall, T. L., and Sachs, G. (1982) The gastric [H, K]ATPase: $\mathrm{H}^{+}$/ATP stoichiometry. J. Biol. Chem. 257, 6296-6299.

38. Blostein, R., Dunbar, L., Mense, M., Scanzano, R., Wilczynska, A., and Caplan, M. J. (1999) Cation selectivity of gastric H,K-ATPase and Na,K-ATPase chimeras. J. Biol. Chem. 274, 18374-18381.

39. Mense, M., Rajendran, V., Blostein, R., and Caplan, M. J. (2002) Extracellular domains, transmembrane segments, and intracellular domains interact to determine the cation selectivity of $\mathrm{Na}, \mathrm{K}$ - and gastric H,K-ATPase. Biochemistry 41, 9803-9812. 